\title{
On-line Sample Preconcentration by Large-volume Sample Stacking with an Electroosmotic Flow Pump (LVSEP) in Microscale Electrophoresis
}

\author{
Fumihiko KITAGaWA, ${ }^{* 1 \dagger}$ Takayuki KaWaI, ${ }^{* 2, * 3}$ and Koji OTSUKA $* 4$ \\ *1 Department of Frontier Materials Chemistry, Graduate School of Science and Technology, \\ Hirosaki University, 3 Bunkyo, Hirosaki, Aomori 036-8561, Japan \\ *2 Department of Applied Chemistry, Graduate School of Engineering, Nagoya University, Furo-cho, Chikusa, \\ Nagoya 464-8603, Japan \\ *3 Department of Chemistry, University of Illinois at Urbana-Champaign, 600 South Mathews Avenue, Urbana, \\ IL 61801, USA \\ *4 Department of Material Chemistry, Graduate School of Engineering, Kyoto University, Katsura, Nishikyo, \\ Kyoto 615-8510, Japan
}

\begin{abstract}
This review highlights on-line sample preconcentration by large-volume sample stacking with an electroosmotic flow pump (LVSEP) in microscale electrophoresis. LVSEP requires only a hydrodynamic sample injection into the whole capillary/microchannel and a constant voltage application, i.e., without polarity switching, providing an efficient sensitivity enhancement with a relatively easy experimental procedure without loss of the separation efficiencies. Recent developments and applications of LVSEP are briefly reviewed from the first LVSEP study in 1999 with categorization on the basis of separation modes, including zone electrophoresis, cyclodextrin- and affinity-based separation modes and non-aqueous capillary electrophoresis.
\end{abstract}

Keywords Capillary electrophoresis, microchip electrophoresis, on-line sample preconcentration, LVSEP, field-amplified sample injection

(Received September 17, 2013; Accepted October 23, 2013; Published December 10, 2013)

1 Introduction

2 LVSEP Combined with CZE

3 LVSEP Combined with CD- and Affinity-based Separation Modes

4 LVSEP Combined with NACE
1129

1130

1134

1135
5 LVSEP Combined with Electrokinetic Injection

6 Conclusions

1136

7 Acknowledgements $\quad 1138$

8 References 1138

\section{Introduction}

Microscale electrophoresis, including capillary electrophoresis
(CE) and microchip electrophoresis (MCE), is a separation technique based on electrophoretic migration in the capillary or microchannel under an applied electric field. In CE and MCE, several advantages can be obtained, such as high separation

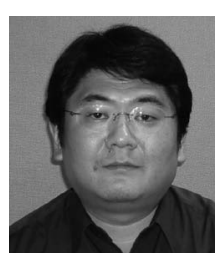

Fumihiko KitagaWA received a Ph.D. degree from Graduate School of Science, Hokkaido University in 2002, concerning laser trapping-microspectroscopy under the supervision of Prof. N. Kitamura. He started his professional career as an Assistant Professor at Kyoto University in 2003, and was then promoted to Lecturer in 2009. In 2011, he became Associate Professor of Graduate School of Science and Technology, Hirosaki University. Currently, his scientific interest is focused on the development of high-performance microscale electrophoretic analysis systems.

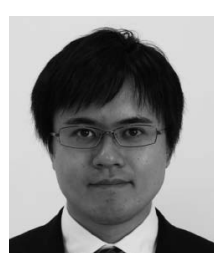

Takayuki KAWAI received a Ph.D. degree from Graduate School of Engineering, Kyoto University in 2012 concerning high-performance microscale electrophoresis under the supervision of Prof. K. Otsuka. He studied centrifugal microfluidics as a postdoctoral fellow of Innovation School in National Institute of Advanced Industrial Science and Technology until 2013. He is now a JSPS postdoctoral fellow of Nagoya University, and is studying high-performance microscale bioanalysis while visiting J. Sweedler's research group in University of Illinois at Urbana-Champaign.

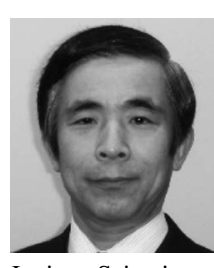

Koji OtsuKa received a D. Eng. degree from Graduate School of Engineering, Kyoto University in 1986 concerning electrokinetic chromatography under the supervision of Prof T. Ando. After working through a JSPS Fellowship for Japanese Junior Scientists, he joined Osaka Prefectural College of Technology in 1988. In 1995, he moved to Faculty of Science, Himeji Institute of Technology. In 2002, he became a Professor of Graduate School of Engineering, Kyoto University. His research area includes microscale high performance separation techniques, $\mu$-TAS, and nano-biodevices.

\footnotetext{
$\dagger$ To whom correspondence should be addressed. E-mail: kitagawa@cc.hirosaki-u.ac.jp
} 
efficiency, short analysis time, and small sample consumption. However, the concentration sensitivity in $\mathrm{CE}$ and MCE is poor due to the short optical path length and the small sample volume. To improve the detection sensitivity, many on-line sample preconcentration techniques have been developed. There are mainly two approaches in the on-line sample preconcentration techniques, i.e., dynamic and static methods. Static preconcentration techniques refer to solid-phase extraction (SPE), liquid-phase microextraction (LPME) and filtration at the inlet of the capillary. ${ }^{1,2}$ These approaches can provide efficient preconcentration, but complicated fabrication and/or experimental procedures are generally required to enrich, elute and separate target analytes. Hence, various dynamic preconcentration methods, including field-amplified stacking, isotachophoretic stacking, $\mathrm{pH}$-mediated stacking and sweeping techniques, have been developed and applied in CE. ${ }^{3-11}$ These techniques are based on changes in the analyte migration velocity at the boundary in two or three discontinuous solutions systems. To stack target analytes, a sample solution whose components differ from those of a background solution (BGS) is injected into the capillary as a long plug. Sudden deceleration of the migration velocity due to the difference in the electric field strength, leading/terminating electrolytes, retention factor and $\mathrm{pH}$ causes the accumulation of the analytes on the BGS/sample boundary. Combining these preconcentration techniques with universal detectors, such as ultraviolet absorption (UV) and capacitively coupled contactless conductivity detection $\left(\mathrm{C}^{4} \mathrm{D}\right)$, and sensitive detection schemes including laser-induced fluorescence (LIF), amperometric detection (AD) and mass spectrometry (MS) have become conventional approaches to compensate for insufficient sensitivity and to obtain higher detectability, respectively.

Among several dynamic preconcentration techniques, field-amplified sample stacking (FASS) is the simplest and most common approach in CE. ${ }^{12}$ In the FASS technique, a low-conductivity sample solution is injected into a capillary filled with a high-conductivity BGS. When a separation voltage is applied to the capillary, the electric field localized in the sample zone is higher than that in the BGS, providing a faster migration velocity of the ionic analytes in the sample region. The resulting difference in the electrophoretic velocities enriches the analytes at the sample/BGS boundary. Under a typical FASS condition, however, an injected sample volume is limited to beless than $5 \%$ of the capillary volume, since a higher sample volume tends to cause serious band broadening. Thus, the preconcentration efficiency of FASS is not high, typically 10 - 100-fold.

To enhance the concentration efficiency, a larger volume of a low-conductivity sample is hydrodynamically injected into the capillary. This technique was first developed by Burgi and Chien, and is called large-volume sample stacking (LVSS). ${ }^{13-15}$ In LVSS, after the FASS concentration at the sample/BGS boundary, the sample matrix (SM) remaining in the capillary is problematic. Since the vacant and long SM (water plug) significantly decreases the electric field in the BGS zone and the effective separation length, the separation performance should be reduced. Thus, the remaining SM zone must be removed immediately after the stacking. Two SM removal techniques are available in LVSS, with or without polarity switching. In LVSS with polarity switching under a normal electroosmotic flow (EOF) condition, a negative voltage is first applied to stack anionic analytes. During stacking, any vacant SM zone is removed by the cathodic EOF. When the current reaches $90-95 \%$ of the steady current, indicating SM removal, the polarity is switched to positive to drive the stacked analytes to the detection point by the EOF. Although the LVSS with polarity switching is more popular than that without polarity switching, a troublesome current monitoring is required, which interferes with the automated LVSS in the commercial CE apparatus. In the case of LVSS without polarity switching, on the other hand, the electrophoretic velocity of the anionic analytes in the SM zone must be faster than the velocity of cathodic EOF. Under the reversal polarity condition, the vacant SM zone remaining after stacking is pumped out by the EOF, though the cathodic end and then the concentrated anions migrate to the detection point. This was originally developed by Burgi, who used diethylenetriamine (DETA) as an additive to reduce the EOF. ${ }^{16}$ In previous LVSS reports, cationic-surfactants system $^{16-27}$ or a non-aqueous CE (NACE) mode ${ }^{28-32}$ were mainly employed to obtain a slower anodic EOF. Despite that the first LVSS study ${ }^{16}$ tried to inject a low-conductivity sample into the whole capillary to obtain a higher concentration efficiency, most LVSS studies have involved optimization of the injection length to be compatible with both the sensitivity and the resolution. Since such optimization may be bothersome, the adjustment of the sample injection length is preferably eliminated. In the application of LVSS without polarity switching to MCE, furthermore, it is difficult to precisely adjust the length of a large volume of the sample due to complicated electrokinetic injection. Therefore, efficient preconcentration by LVSS without polarity switching and with whole capillary/microchannel sample-injection is desired.

He and Lee developed LVSS without polarity switching by simply suppressing the EOF in the separation stage with an acidic BGS. ${ }^{33}$ They termed this approach LVSS with an EOF pump (LVSEP), where up to the entirely injected sample in the capillary is efficiently concentrated and separated in a single run. From the first study of LVSEP in 1999, further technical developments, theoretical verifications and various applications have proceeded. In this review, we focus on the on-line sample preconcentration by LVSEP with (almost) whole capillary/ microchannel sample-injection, since the preconcentration approach can provide sensitivity enhancements without a loss of resolution with an easy experimental procedure. Applications of LVSEP are briefly reviewed along with categorization on the basis of separation modes, including capillary zone electrophoresis (CZE), cyclodextrin (CD)- and affinity-based separation modes and NACE.

\section{LVSEP Combined with CZE}

Figure 1 shows schematics of the basic principle of LVSEP. In the first report on LVSEP, ${ }^{33}$ an extremely large volume, e.g., $80-100 \%$ of the capillary, of a sample prepared in pure water is injected into a capillary filled with acidic BGS. After the voltage application, anionic analytes are concentrated at the SM/ BGS boundary by the difference in the electric field strength between the two zones (Figs. $1 \mathrm{~b}$ and 1c). Since most of the capillary is filled with the aqueous sample plug during the initial stage of the sample stacking, much higher resistivity and $\mathrm{pH}$ of the SM provides a faster EOF in the capillary. Hence, the focused analytes move toward the cathode by the EOF, and the vacant SM zone is quickly pumped out at the cathodic end. As the BGS with a high ionic strength $(I)$ is introduced into the capillary, the EOF velocity becomes slower. When most of the $\mathrm{SM}$ is removed from the cathodic end, the electric field in the BGS zone becomes higher. As a result, the electrophoretic velocity of the analyte exceeds the EOF velocity, resulting in an inversion of the moving direction of the analytes (Fig. 1d). 

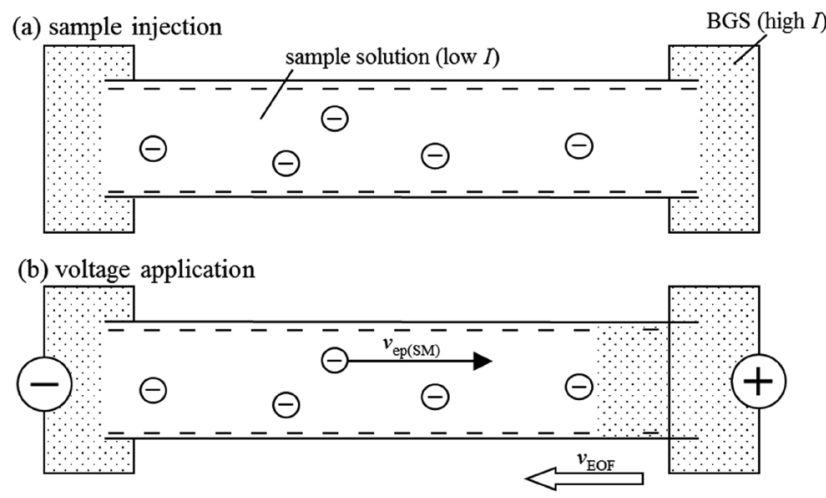

(c) sample stacking and SM removal

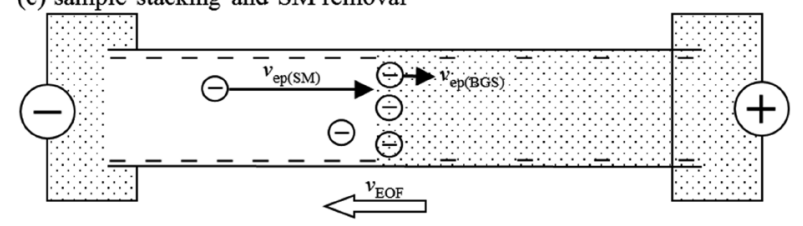

(d) complete of SM removal and start of CZE separation

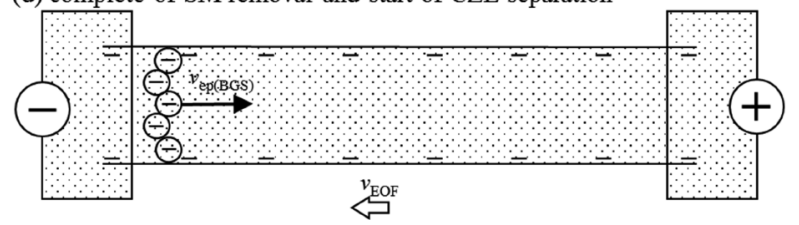

Fig. 1 Schematic illustration of the matrix removal and stacking of small anions in acidic buffer: (a) injection of extremely large volume of sample containing small anions by pressure, (b) start of anions stacking and removal of aqueous sample plug under negative voltage, (c) process of anion stacking and removal of aqueous sample plug, (d) complete removal of the aqueous sample plug and start of separation under a negative voltage. [Reprinted with permission from Anal. Chem., 1999, 71, 995. Copyright 1999 American Chemical Society.]

After complete removal of the SM, the anionic analytes are separated by CZE during anodic migration. In this way, the sample stacking and separation can be consecutively performed under the same negative voltage without the loss of stacked anions and effective separation length. In the LVSEP system, therefore, a faster EOF in the SM plug and a slower EOF in the BGS zone should be necessary to remove the analyte-free SM and to drive concentrated anionic analytes toward anodic end without polarity switching, respectively.

To fulfill such a condition, He and Lee simply used the acidic BGS (pH 3.0) and sample dissolved in deionized water for the separation of fumaric acid (FUMA), maleic acid (MALE), nitrate and bromide ions in a bare fused-silica capillary. ${ }^{33}$ In this condition, the electrophoretic mobilities of these analytes ranged from -3.7 to $-8.9 \times 10^{-4} \mathrm{~cm}^{2} / \mathrm{V} \cdot \mathrm{s}$, while the EOF mobilities in the capillary filled with the acidic BGSs $(\mathrm{pH}<4)$ were $+0.6-+0.8 \times 10^{-4} \mathrm{~cm}^{2} / \mathrm{V} \cdot \mathrm{s}$. Since the absolute values of the electrophoretic mobilities exceeded those of the EOF mobilities, the analytes could migrate against EOF toward the anode. By employing LVSEP, these anions were well separated and concentrated with a more than 300-fold enrichment in a few minutes. They also confirmed that the stacked anions did not reach the edge of the capillary inlet, and the loss of stacked anions was avoided during LVSEP and separation processes.

After the first study on LVSEP, several research groups have attempted the use of neutral and basic BGSs $(\mathrm{pH}>6)$ to widen the applicability of LVSEP to various analytes (Table 1). In the tables, the value of the calculated sensitive enhancement factor
(SEF) is given. This was obtained by comparing the peak height determined in the LVSEP condition with that in the conventional $\mathrm{CE}$, while taking into account the dilution factor regardless of the injection volume of the sample solution. Chung's group reported the use of $\mathrm{pH}$ hysteresis of the EOF in a bare fusedsilica capillary. ${ }^{34}$ In this study, a fused-silica capillary was pretreated with $0.01 \mathrm{M} \mathrm{HCl}$ to suppress the EOF. Due to the slow deprotonation equilibrium of the silanol group at an intermediate $\mathrm{pH}$, the reduced EOF could be retained during electrophoresis runs. As a typical result, successful LVSEP at pH 6.0 was achieved for weakly acidic compounds with two orders of magnitude enhancements in the concentration sensitivity. The same research group exhaustively investigated the application of a polymer-coated capillary to LVSEP under the reduced EOF condition. ${ }^{35-38}$ When a reversal potential was applied to a capillary filled with a sample dissolved in distilled water, the reduced but still existing EOF pushed the vacant SM plug out of the capillary. After SM removal, the EOF in the capillary filled with the BGS ( $\mathrm{pH}$ 6.0) was further reduced due the increased $I$. Hence, the stacked analytes switched the migration direction toward the detector. They employed several coated-capillaries, including $100 \%$ dimethyl polysiloxane (DB-1), linear polyacrylamide (LPA), cross-linking and bonding proprietary fluorocarbon polymer ( $\mu$ SIL-FC) and polyethylene oxide (PEO) coatings to preconcentrate and separate amino acids, ${ }^{35,37}$ proteins, ${ }^{36}$ weak organic acids, ${ }^{37}$ chlorophenols ${ }^{37,38}$ and nitrophenols $^{38}$ at $\mathrm{pH} 6.0-11.0$. As a unique application, automated coupling of headspace-single drop microextraction (HS-SDME) with LVSEP-CE was demonstrated using a commercial CE instrument. By using a drop hanging at the inlet tip of a capillary as the acceptor phase, HS-SDME was successfully combined with LVSEP (Fig. 2). ${ }^{38}$ As shown in Fig. 2d, the sensitivity could be improved with the SEFs for phenolic compounds ranging from 1900 to 3400. Zhu et al. used hydroxyethylcellulose (HEC) as a BGS modifier to suppress the EOF under an acidic condition $(\mathrm{pH} 4.1)$ for determining ethylenediaminetetraacetic acid (EDTA) in drinking water by LVSEP-CZE. ${ }^{39}$ Due to the cooperative EOF-reducing ability of HEC and acidic BGS, the detection limit of EDTA was improved 1000-fold in the LVSEP method. Kuo et al. reported a similar approach using the BGS containing PEO for the determination of methotrexate and its metabolites in human plasma, achieving a SEF of around 100.40 These polymercoated capillaries and polymer modifiers are suitable for the LVSEP-CZE analysis of fast-migrating anions.

Recently, our research group employed LVSEP to the MCE analysis of oligosaccharides that were labeled with anionic 8-aminopyrene-1,3,6-trisulfonic acid (APTS). ${ }^{41}$ In LVSEPMCE, only a sample injection throughout a "single" straight channel and application of a constant voltage between both ends of the single channel are required, simplifying the experimental procedure and improving the detection sensitivity in MCE. Of course, the analysis time is dramatically reduced in MCE compared to conventional CE. To suppress both EOF and sample adsorption onto the microchannel surface, poly(vinyl alcohol) (PVA) was permanently modified on the poly(dimethylsiloxane) (PDMS) microchips. As well as other polymer-coated capillaries, an enhanced EOF was observed in the PVA-coated microchannel filled with a low ionic-strength sample solution. In this work, the electroosmotic mobility in a sample zone prepared from deionized water was successfully estimated to be $+4.4 \times 10^{-4} \mathrm{~cm}^{2} / \mathrm{V} \cdot \mathrm{s}$ for the first time. This faster EOF on a PVA-coated microchannel can be explained by Debye-Hückel theory, i.e., the EOF mobility is proportional to $I^{-1 / 2}$. Hence, it was revealed that such faster EOF in the sample 
Table 1 Applications of LVSEP in $\mathrm{CZE}^{\mathrm{a}}$

\begin{tabular}{|c|c|c|c|c|c|c|c|c|c|}
\hline Target analyte & $\begin{array}{l}\text { Preconcentration } \\
\text { and separation } \\
\text { mode, and } \\
\text { detection } \\
\text { scheme }\end{array}$ & $\begin{array}{l}\text { Capillary and } \\
\text { microchip } \\
\text { coating }\end{array}$ & BGS & $\begin{array}{l}\text { Injection } \\
\text { amount }\end{array}$ & Application & LOD & SEF & Comment & Ref. \\
\hline $\begin{array}{l}\text { Nitrate and bromide } \\
\text { ions, fumaric and } \\
\text { maleic acids }\end{array}$ & $\begin{array}{l}\text { LVSEP-CZE- } \\
\text { UV }\end{array}$ & Bare & $\begin{array}{c}50 \mathrm{mM} \text { phosphate } \\
\text { buffer (pH 2.68) }\end{array}$ & $87 \%(53 \mathrm{~cm})$ & $\begin{array}{l}\text { Trace } \\
\text { analysis in } \\
\text { analytical- } \\
\text { grade } \\
\text { reagents }\end{array}$ & $3 \mathrm{ppb}$ & $>300$ & & 33 \\
\hline $\begin{array}{l}\text { Aromatic acids, } \\
\text { nucleoside } \\
\text { triphosphate }\end{array}$ & $\begin{array}{l}\text { LVSEP-CZE- } \\
\text { UV }\end{array}$ & Bare & $\begin{array}{l}50 \text { mM phosphate/ } \\
\text { citrate buffer } \\
(\mathrm{pH} \mathrm{6.0)}\end{array}$ & Full $(27 \mathrm{~cm})$ & & $\begin{array}{c}5-20 \\
\mathrm{nM}\end{array}$ & $150-250$ & $\begin{array}{l}\text { Precondi- } \\
\text { tioning } \\
\text { with } 0.01 \\
\mathrm{M} \mathrm{HCl}\end{array}$ & 34 \\
\hline $\begin{array}{l}\text { Five nonprotein } \\
\text { amino acids }\end{array}$ & $\begin{array}{l}\text { LVSEP-CZE- } \\
\text { UV }\end{array}$ & DB-1 & $\begin{array}{l}50 \mathrm{mM} \text { Tris/citrate } \\
\text { buffer }(\mathrm{pH} 6.0)\end{array}$ & Full $(57 \mathrm{~cm})$ & & $\begin{array}{c}8-15 \\
\mathrm{nM}\end{array}$ & $250-500$ & & 35 \\
\hline $\begin{array}{l}\text { Trypsin inhibitor, } \\
\alpha \text {-lactalbumin }\end{array}$ & $\begin{array}{l}\text { LVSEP-CZE- } \\
\text { UV }\end{array}$ & $\begin{array}{l}\text { LPA, } \mu \text { SIL- } \\
\text { FC coating }\end{array}$ & $\begin{array}{l}100 \mathrm{mM} \text { Tris/ } \\
\text { borate buffer } \\
(\mathrm{pH} 8.0)\end{array}$ & Full $(27 \mathrm{~cm})$ & & $\begin{array}{l}5.0-7.0 \\
\text { fmol }\end{array}$ & & & 36 \\
\hline $\begin{array}{l}\text { Six weak organic } \\
\text { acids }\end{array}$ & $\begin{array}{l}\text { LVSEP-CZE- } \\
\text { UV }\end{array}$ & DB-1, PEO & $\begin{array}{c}50 \mathrm{mM} \text { Tris/citrate } \\
\text { buffer }(\mathrm{pH} 6.0)\end{array}$ & Full $(27 \mathrm{~cm})$ & & $\begin{array}{l}10-50 \\
\mathrm{nM}\end{array}$ & $125-170$ & & 37 \\
\hline $\begin{array}{l}\text { Four trichlorophenols } \\
\text { and five } \\
\text { dichlorophenols }\end{array}$ & $\begin{array}{l}\text { LVSEP-CZE- } \\
\text { UV }\end{array}$ & LPA & $\begin{array}{l}40 \mathrm{mM} \text { borate } \\
\text { buffer (pH 8.0, } \\
9.0)\end{array}$ & Full $(27 \mathrm{~cm})$ & & $10 \mathrm{nM}$ & $140-170$ & & 37 \\
\hline Tyr, Phe, Trp & $\begin{array}{l}\text { LVSEP-CZE- } \\
\text { UV }\end{array}$ & $\begin{array}{c}\mu \mathrm{SIL}-\mathrm{FC} \\
\text { coating }\end{array}$ & $\begin{array}{l}20 \mathrm{mM} \text { borate } \\
(\mathrm{pH} 10.0) / 20 \mathrm{mM} \\
\text { phosphate } \\
(\mathrm{pH} \mathrm{11.0)}\end{array}$ & Full $(27 \mathrm{~cm})$ & & $\begin{array}{l}20-80 \\
\mathrm{nM}\end{array}$ & $80-160$ & & 37 \\
\hline $\begin{array}{l}\text { Nitro and } \\
\text { chlorophenols }\end{array}$ & $\begin{array}{l}\text { LVSEP-CZE- } \\
\text { UV }\end{array}$ & $\begin{array}{l}\mu \mathrm{SIL}-\mathrm{FC} \\
\text { coating }\end{array}$ & $\begin{array}{l}400 \mathrm{mM} \text { borate } \\
\text { buffer }(\mathrm{pH} 9.2)\end{array}$ & Full $(60 \mathrm{~cm})$ & & & $83-88$ & & 38 \\
\hline $\begin{array}{l}\text { Nitro and } \\
\text { chlorophenols }\end{array}$ & $\begin{array}{l}\text { HS-SDME- } \\
\text { LVSEP-CZE- } \\
\text { UV }\end{array}$ & $\begin{array}{c}\mu \mathrm{SIL}-\mathrm{FC} \\
\text { coating }\end{array}$ & $\begin{array}{l}400 \mathrm{mM} \text { borate } \\
\text { buffer (pH 9.2) }\end{array}$ & Full $(60 \mathrm{~cm})$ & Red wine & $\begin{array}{l}0.3-1.0 \\
\mathrm{nM}\end{array}$ & $\begin{array}{c}1900- \\
3400\end{array}$ & & 38 \\
\hline EDTA & $\begin{array}{l}\text { LVSEP-CZE- } \\
\text { UV }\end{array}$ & HEC & $\begin{array}{l}0.05 \% \\
\text { HEC/50 mM } \\
\text { borate-phosphate } \\
\text { buffer (pH 4.1) }\end{array}$ & Full (49 cm) & Drink water & $0.2 \mu \mathrm{g} / \mathrm{L}$ & 1000 & & 39 \\
\hline $\begin{array}{l}\text { Methotrexate and its } \\
\text { metabolites }\end{array}$ & $\begin{array}{l}\text { LVSEP-CZE- } \\
\text { UV }\end{array}$ & PEO & $\begin{array}{l}0.01 \% \mathrm{PEO} / 70 \mathrm{mM} \\
\text { phosphate buffer } \\
(\mathrm{pH} \mathrm{6.0)}\end{array}$ & 3 psi for $70 \mathrm{~s}$ & Plasma & $\begin{array}{c}0.05- \\
0.10 \\
\mu \mathrm{M}\end{array}$ & $\sim 100$ & $\begin{array}{l}-70 \% \text { of } \\
40.2 \mathrm{~cm} \\
\text { capillary }\end{array}$ & 40 \\
\hline $\begin{array}{l}\text { Glucose ladder, } \\
\text { glycoprotein- } \\
\text { derived } \\
\text { oligosaccharides }\end{array}$ & $\begin{array}{l}\text { LVSEP- } \\
\text { MCZE-LIF }\end{array}$ & PVA & $\begin{array}{l}25 \text { mM HEPES } \\
\text { buffer (pH 8.0) }\end{array}$ & Full $(8 \mathrm{~cm})$ & & & $\begin{array}{c}2200- \\
2900\end{array}$ & & 41 \\
\hline $\begin{array}{l}\text { Glucose ladder, } \\
\text { glycoprotein- } \\
\text { derived } \\
\text { oligosaccharides }\end{array}$ & $\begin{array}{l}\text { LVSEP-CZE- } \\
\text { LIF }\end{array}$ & PVA & $\begin{array}{l}25 \text { mM HEPES } \\
\text { buffer (pH 8.0) }\end{array}$ & Full $(60 \mathrm{~cm})$ & & $2 \mathrm{pM}$ & $400-770$ & & 42 \\
\hline $\begin{array}{l}\text { Benzylamine, } \\
\text { 1-naphthyle- } \\
\text { thylamine }\end{array}$ & $\begin{array}{l}\text { LVSEP-CZE- } \\
\text { UV }\end{array}$ & $\begin{array}{l}\text { PVA + PAA, } \\
\text { poly(AAran- } \\
\text { MPAC), } \\
\text { DODAB + } \\
\text { POES }\end{array}$ & $\begin{array}{l}40 \mathrm{mM} \text { phosphate } \\
\text { buffer (pH 3.0) }\end{array}$ & Full $(60 \mathrm{~cm})$ & & & $290-550$ & & 43 \\
\hline $\begin{array}{l}\text { Lysozyme, } \\
\alpha \text {-chymo- } \\
\text { trypsinogen } \mathrm{A}, \\
\text { cytochrome } c, \\
\text { ribonuclease } \mathrm{A}\end{array}$ & $\begin{array}{l}\text { LVSEP-CZE- } \\
\text { UV }\end{array}$ & $\begin{array}{l}\text { DODAB + } \\
\text { POES }\end{array}$ & $\begin{array}{l}40 \mathrm{mM} \text { phosphate } \\
\text { buffer (pH 3.0) }\end{array}$ & Full $(60 \mathrm{~cm})$ & & & 1700 & & 43 \\
\hline
\end{tabular}

a. DB-1, 100\% dimethyl polysiloxane; LPA, linear polyacrylamide; $\mu$ SIL-FC, cross-linking and bonding proprietary fluorocarbon polymer; PEO, polyethylene oxide; PVA, poly(vinyl alcohol); MCZE, microchip zone electrophoresis; PAA, poly(allylamine); poly(AAran-MPAC), covalent modification with a random copolymer synthesized from acrylamide and 3-(methacryloylamino)propyltrimethylammonium chloride; DODAB + POES, dimethyldioctadecylammonium bromide and polyoxyethylene 40 stearate; HS-SDME, headspace-single drop microextraction. 

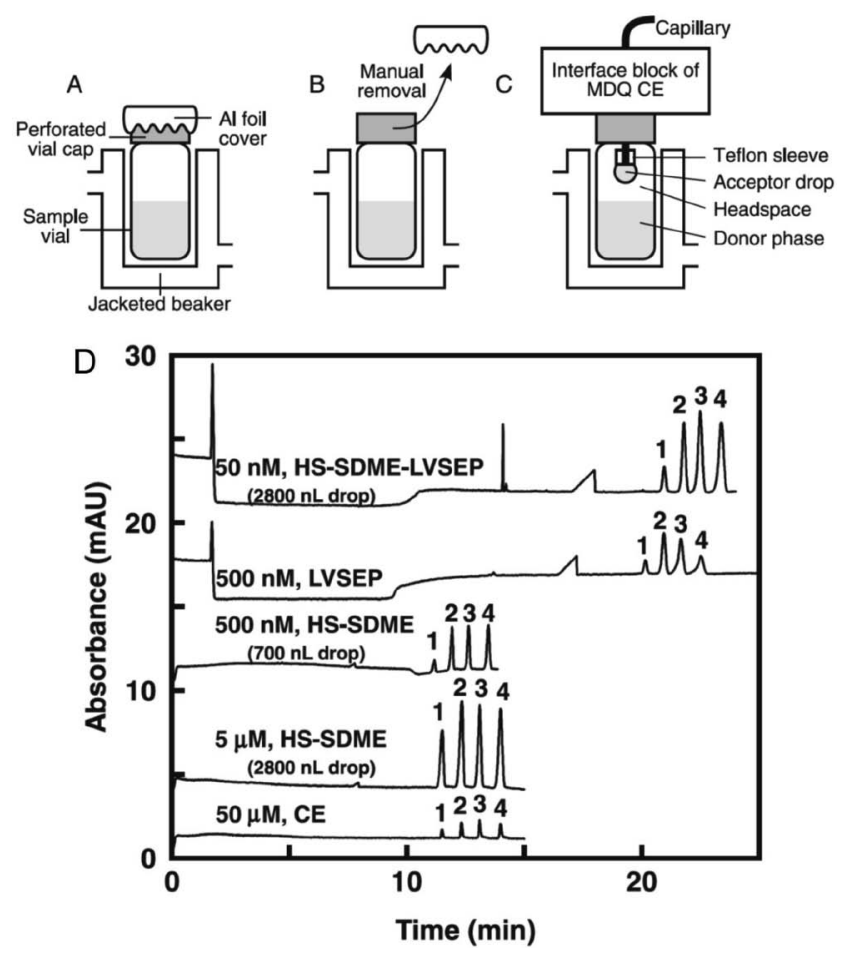

Fig. 2 Electropherograms of CE, HS-SDME, LVSEP, and HSSDME-LVSEP. Peak identification: (1) 2-nitrophenol (2-NP), (2) 2,6-dichlorophenol (2,6-DCP), (3) 2,3,6-trichlorophenol (TCP), (4) 2,4,6-TCP. [Reprinted with permission from Electrophoresis, 2012, 33, 2961. Copyright 2012 WILEY-VCH Verlag GmbH \& Co. KGaA, Weinheim.]

zone worked as the driving force to remove the SM on the polymer-coated capillary and microchannel. When oligosaccharides were analyzed by LVSEP-microchip zone electrophoresis (MCZE) in the PVA-coated straight channel, both the glucose ladder and oligosaccharides obtained from bovine ribonuclease B were well enriched and separated with up to a 2200-2900-fold sensitivity enhancement compared to those in a conventional MCZE analysis (Fig. 3). It should be emphasized that the mechanism of LVSEP in the polymercoated microchannel was also theoretically verified by fluorescence imaging on the microchip in the same report. Among several findings, it was important that both the observed and theoretically-calculated inversion position in the microchannel at the switching from the LVSEP preconcentration to the MCZE separation stage were well accorded. By fluorescence imaging of the LVSEP process in the $40 \mathrm{~mm}$-long PVA-coated channel, it was observed that the moving direction of the stacked analytes was inverted to the anode at the channel position of 3-4 mm from the cathodic end, i.e., more than $90 \%$ of the whole channel length could be utilized for the zone electrophoresis separation at the electrolyte concentrations of 0 to $0.2 \mathrm{mM}$ in BGS. Since the moving direction of the analytes was inversed near the cathodic end, the loss of an effective separation length was negligible in LVSEP. Therefore, the LVSEP technique can give both a good enrichment factor and a high separation performance. In CE, the LVSEP technique based on the PVA-coated capillary is also effective to preconcentrate anionic biomolecules. We applied this technique to the CE analysis of oligosaccharides. ${ }^{42}$ In the LVSEP-CZE analysis of oligosaccharides, up to a 2500-fold sensitivity improvement and good resolution utilizing a long effective (a) conventional MCE

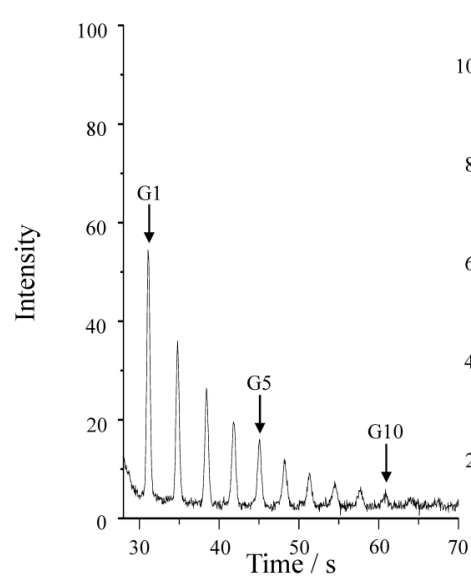

(b) LVSEP-MCE

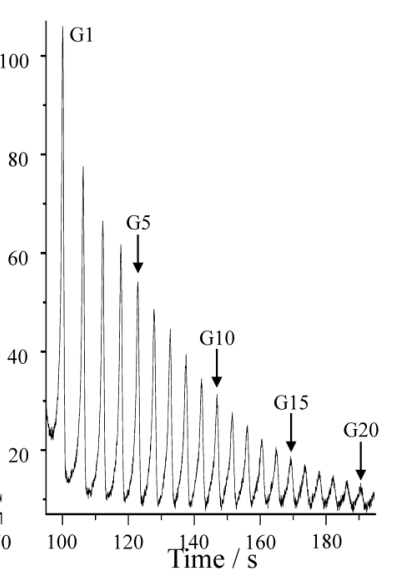

Fig. 3 Electropherograms of glucose ladder obtained with (a) conventional MCE and (b) LVSEP-MCE. Concentration of glucose ladder: (a) $160 \mathrm{ppb}$, (b) 320 ppt. [Reprinted with permission from Anal. Chem., 2010, 82, 6504. Copyright 2010 American Chemical Society.]

separation length with $95 \%$ of the total length were achieved. Furthermore, we found that a conductivity ratio $\left(\sigma_{\mathrm{BGS}} / \sigma_{\mathrm{SM}}\right)$ larger than 20 and an electrolyte concentration of the sample less than $0.15 \mathrm{mM}$ were needed to obtain the LVSEP effect. In the analysis of biomolecules, such a low electrolyte concentration SM should be prepared by gel filtration or dialysis to remove excess labeling reagents after fluorescence derivatization.

In LVSEP, anionic analytes have been mainly analyzed because cationic analytes are flushed out by the EOF from the cathodic end. Thus, a reversal EOF is required to prevent the cationic sample efflux. To extend the applicability of LVSEP to cations, we investigated that inner surface of the capillary was modified with slightly and positively-charged polymers to obtain the EOF basically suppressed but enhanced only in the low I sample solution. ${ }^{43}$ Three capillary modification methods were employed: thermally passivated physical coating with polymer mixture of PVA and poly(allylamine) (PAA); covalent modification with random copolymer of acryl amide and 3-(methacryloylamino)propyltrimethylammonium chloride (poly(AA-ran-MPAC)); easily preparable physical coating with dimethyldioctadecylammonium bromide (DODAB) and polyoxyethylene stearate (POES). In these capillaries, the EOF was well suppressed in the high- $I$ electrolyte under both acidic and basic $\mathrm{pH}$, whereas the EOF was enhanced in the low- $I$ electrolyte, indicating a suitable EOF property for the rapid LVSEP and following separation. In the LVSEP-CZE analyses of cationic amines, up to 550-fold sensitivity increases were successfully obtained in the three capillaries. This approach was applied to the LVSEP-CZE analysis of basic proteins, where up to 100-fold sensitivity increases were achieved, but a peak broadening was observed due to the sample adsorption in the low- $I$ sample matrix. Therefore, more efficient and easier modification methods should be introduced for higher performance LVSEP-CE analysis of cations, especially for proteins. 
Table 2 Applications of LVSEP in CD- and affinity ligand-based modes ${ }^{\mathrm{a}}$

\begin{tabular}{|c|c|c|c|c|c|c|c|c|c|}
\hline Target analyte & $\begin{array}{l}\text { Preconcentration } \\
\text { and separation } \\
\text { mode, and } \\
\text { detection } \\
\text { scheme }\end{array}$ & $\begin{array}{l}\text { Capillary } \\
\text { coating }\end{array}$ & BGS & $\begin{array}{l}\text { Injection } \\
\text { amount }\end{array}$ & Application & LOD & SEF & Comment & Ref. \\
\hline $\begin{array}{l}\text { Oxacillin, cloxacillin } \\
\text { and dicloxacillin }\end{array}$ & $\begin{array}{l}\text { LVSEP- } \\
\text { CDCZE-UV }\end{array}$ & Bare & $\begin{array}{l}5.2 \mathrm{mM} \text { HP- } \beta-\mathrm{CD} / \\
50 \mathrm{mM} \text { phosphate } \\
\text { buffer (pH 3.6) }\end{array}$ & Full $(49 \mathrm{~cm})$ & Milk & $2.0 \mu \mathrm{g} / \mathrm{L}$ & & & 44 \\
\hline $\begin{array}{l}\text { Racemic warfarin, } \\
\text { ibuprofen }\end{array}$ & $\begin{array}{l}\text { LVSEP- } \\
\text { CDCZE-UV }\end{array}$ & PVA & $\begin{array}{l}10 \mathrm{mM} \text { DM- } \beta-\mathrm{CD} \\
\text { or } 40 \mathrm{mM} \\
\text { TM- } \beta \text {-CD/25 } \\
\text { mM MES buffer } \\
\text { (pH 6.0) }\end{array}$ & Full $(60 \mathrm{~cm})$ & Urine & $\begin{array}{l}3.7- \\
4.7 \mathrm{ppb}\end{array}$ & $500-1000$ & & 45 \\
\hline $\begin{array}{l}\text { Abscisic acid } \\
\text { enantiomers }\end{array}$ & $\begin{array}{l}\text { LVSEP- } \\
\text { CDEKC-UV }\end{array}$ & PVA & $\begin{array}{l}1.5 \mathrm{mM} \\
\text { quaternary } \\
\text { ammonium- } \beta \text { - } \\
\mathrm{CD} / 20 \mathrm{mM} \mathrm{MES} \\
\text { buffer (pH 6.0) }\end{array}$ & Full $(60 \mathrm{~cm})$ & & & 800 & & 45 \\
\hline $\begin{array}{l}\text { Racemic Arg, Met, } \\
\text { Leu }\end{array}$ & $\begin{array}{l}\text { LVSEP- } \\
\text { CDMEKC- } \\
\text { LIF/UV }\end{array}$ & PVA & $\begin{array}{l}30 \mathrm{mM} \text { SDS, } \\
10 \mathrm{mM} \gamma-\mathrm{CD}, \\
40 \mathrm{mM} \text { borate } \\
\text { buffer (pH 9.5) }\end{array}$ & Full $(60 \mathrm{~cm})$ & & & $\begin{array}{r}1000- \\
1300\end{array}$ & & 45 \\
\hline $\begin{array}{l}\text { Chlorpheniramine } \\
\text { and bromphenir- } \\
\text { amine enatiomers }\end{array}$ & $\begin{array}{l}\text { LVSEP- } \\
\text { CDCZE-UV }\end{array}$ & $\begin{array}{l}\text { DODAB + } \\
\text { POES }\end{array}$ & $\begin{array}{l}5 \mathrm{mM} \beta-\mathrm{CD} / \\
40 \mathrm{mM} \\
\text { phosphate buffer } \\
\text { (pH 3.0) }\end{array}$ & Full $(60 \mathrm{~cm})$ & & & $360-380$ & & 43 \\
\hline $\begin{array}{l}\text { Glycoprotein-derived } \\
\text { oligosaccharides }\end{array}$ & $\begin{array}{l}\text { LVSEP- } \\
\text { PFACE-LIF }\end{array}$ & PDMS & $\begin{array}{l}0.5 \% \mathrm{HPC} / \\
100 \mathrm{mM} \text { Tris- } \\
\text { acetate buffer } \\
(\mathrm{pH} 7.0)\end{array}$ & Full $(50 \mathrm{~cm})$ & & $0.3 \mathrm{nM}$ & 900 & $\begin{array}{l}\text { Lectin } \\
\text { affinity }\end{array}$ & 46 \\
\hline
\end{tabular}

a. PVA, poly(vinyl alcohol); HP- $\beta$-CD, 2-hydroxypropyl- $\beta$-CD; DM- $\beta$-CD, 2,6-di- $O$-methyl- $\beta$-CD; TM- $\beta$-CD, $2,3,6$-tri- $O$-methyl- $\beta$-CD; DODAB + POES, dimethyldioctadecylammonium bromide and polyoxyethylene 40 stearate; PDMS, polydimethylsiloxane; PFACE, partial filling affinity capillary electrophoresis.

\section{LVSEP Combined with CD- and Affinity-based Separation Modes}

In the chapters 3 and 4 , the application of LVSEP to separation modes other than CZE is described. Especially for analyzing chiral compounds, the application of LVSEP to the CD-based separation modes, such as CD-modified CZE (CDCZE), CD electrokinetic chromatography (CDEKC) and CD-modified micellar electrokinetic chromatography (CDMEKC), is desired. In the first coupling of LVSEP with the CD-based separation mode, Zhu et al. analyzed "achiral" isoxazolylpenicillins by LVSEP-CDCZE using an acidic BGS and 2-hydroxypropyl- $\beta$ $\mathrm{CD}(\mathrm{HP}-\beta-\mathrm{CD})$ as the EOF suppressor and selective complexforming BGS additive, respectively. ${ }^{44}$ The addition of HP- $\beta$-CD into the BGS could improve the separation of isoxazolylpenicillins. LVSEP was also successfully applied to improve the sensitivity, where the detection limits were found to be $2.0 \mu \mathrm{g} / \mathrm{L}$. Recently, our research group theoretically and experimentally investigated the effects of the addition of CDs into a BGS on the LVSEP preconcentration of chiral compounds. ${ }^{45}$ From theoretical considerations, it was confirmed that, even in the CD-based separation modes, the loss of an effective separation length would be more minimized by reducing the salt concentration of the SM, and by making the conductivity of the BGS high so as to provide a large enough $\sigma_{\mathrm{BGS}} / \sigma_{\mathrm{SM}}$. In the PVA-coated capillary, LVSEP was combined with CDCZE, CDEKC and CDMEKC for the separation of drug components (warfarin and ibuprofen), abscisic acid and amino acid enantiomers, respectively, with the SEFs ranging from 500 to 1300 , as summarized in Table 2. By sample-desalting with a $\mathrm{C}_{18}$ solid-phase extraction column, $250 \mathrm{ppb}$ racemic ibuprofen in urine could be detected by LVSEP-CDCZE without diluting the sample. LVSEP-CDCZE was also applied to the chiral separation of cationic racemates, chlorpheniramine and brompheniramine, in a DODAB + POES coated capillary, resulting in up to a 380-fold sensitivity enhancement with keeping the baseline separation for the enantiomers. ${ }^{43}$

Fukushima et al. combined LVSEP with partial filling affinity capillary electrophoresis (PFACE) to realize a highly sensitive analysis of the interaction of glycoprotein-derived oligosaccharides with some plant lectins. ${ }^{46}$ By injecting lectin from the anodic end as a short plug for PFACE, followed by the injection of a sample solution to the entire capillary for LVSEP, anionic APTS-labeled oligosaccharides were continuously moved and stacked in the lectin plug until completion of the preconcentration, which would enhance the interaction efficiency of oligosaccharides with lectins. In PFACE-LVSEP, a PDMS-coated capillary and a BGS containing hydroxypropylcellulose (HPC) was used to suppress the EOF and analytes/lectin surface adsorption. Effective preconcentration by LVSEP and good resolution of APTS derivatives of glycoprotein derived oligosaccharides by PFACE was achieved with a SEF of $c a$. 900. It should be noted that, for the LVSEP- 
Table 3 Applications of LVSEP in NACE ${ }^{a}$

\begin{tabular}{|c|c|c|c|c|c|c|c|c|c|}
\hline Target analyte & $\begin{array}{l}\text { Preconcentration } \\
\text { and separation } \\
\text { mode, and } \\
\text { detection } \\
\text { scheme }\end{array}$ & Capillary & BGS & $\begin{array}{l}\text { Injection } \\
\text { amount }\end{array}$ & Application & LOD & SEF & Comment & Ref. \\
\hline Ten benzoic acids & $\begin{array}{l}\text { LVSEP- } \\
\text { NACE-UV }\end{array}$ & Bare & $\begin{array}{l}25 \mathrm{mM} \text { Tris/ } \\
\text { acetate (25:9.9 } \\
\text { v/v, pH 8.0) in } \\
\text { methanol }\end{array}$ & Full $(57 \mathrm{~cm})$ & & $2-8 \mathrm{nM}$ & & & 47 \\
\hline $\begin{array}{l}\text { Six nonsteroidal } \\
\text { anti-inflammatory } \\
\text { drugs }\end{array}$ & $\begin{array}{l}\text { LVSEP- } \\
\text { NACE-UV }\end{array}$ & Bare & $\begin{array}{l}20-30 \mathrm{mM} \text { borate } \\
(\mathrm{pH} 9.6) / 60- \\
80 \% \text { methanol }\end{array}$ & Full $(52 \mathrm{~cm})$ & $\begin{array}{c}\text { Bottled } \\
\text { water }\end{array}$ & $\begin{array}{l}10- \\
35 \mu \mathrm{g} / \mathrm{L}\end{array}$ & $45-100$ & & 48 \\
\hline $\begin{array}{l}\text { Five nonsteroidal } \\
\text { anti-inflammatory } \\
\text { drugs }\end{array}$ & $\begin{array}{l}\text { LVSEP- } \\
\text { NACE-UV }\end{array}$ & Bare & $\begin{array}{l}30 \mathrm{mM} \text { borate } \\
(\mathrm{pH} 9.8) / 70 \% \\
\text { methanol }\end{array}$ & Full $(52 \mathrm{~cm})$ & & $\begin{array}{l}10- \\
35 \mu \mathrm{g} / \mathrm{L}\end{array}$ & $85-100$ & & 49 \\
\hline $\begin{array}{l}\text { Five halogenated } \\
\text { phenols }\end{array}$ & $\begin{array}{l}\text { LVSEP- } \\
\text { NACE-UV }\end{array}$ & Bare & $\begin{array}{l}20 \mathrm{mM} \text { borate } \\
(\mathrm{pH} 9.4) / \\
\text { methanol }\end{array}$ & $\begin{array}{l}50 \mathrm{mbar} \text { for } \\
300 \mathrm{~s}\end{array}$ & Waste water & $\begin{array}{l}1.3- \\
5.5 \\
\mu \mathrm{g} / \mathrm{L}\end{array}$ & $82-333$ & $\begin{array}{l}-85 \% \text { of } \\
70 \mathrm{~cm} \\
\text { capillary }\end{array}$ & 50 \\
\hline $\begin{array}{l}\text { Five halogenated } \\
\text { phenols }\end{array}$ & $\begin{array}{l}\text { LVSEP- } \\
\text { NACE-UV }\end{array}$ & Bare & $\begin{array}{l}20 \mathrm{mM} \text { borate } \\
(\mathrm{pH} \mathrm{9.4)/} \\
\text { methanol }\end{array}$ & $\begin{array}{l}50 \mathrm{mbar} \text { for } \\
300 \mathrm{~s}\end{array}$ & $\begin{array}{l}\text { River and } \\
\text { waste } \\
\text { water }\end{array}$ & $\begin{array}{l}0.4- \\
1.7 \mu \mathrm{g} / \mathrm{L}\end{array}$ & & $\begin{array}{l}\sim 85 \% \text { of } \\
70 \mathrm{~cm} \\
\text { capillary }\end{array}$ & 51 \\
\hline $\begin{array}{l}\text { Pentachlorophenol, } \\
\text { 3-bromobenzoic } \\
\text { acid, 4-iodobenzoic } \\
\text { acid }\end{array}$ & $\begin{array}{l}\text { LVSEP- } \\
\text { NACE-UV }\end{array}$ & Bare & $\begin{array}{l}25 \mathrm{mM} \text { Tris/ } \\
\text { acetate }(25: 9.9, \\
\text { v/v, } \mathrm{pH} 8.0) / \\
\text { methanol }\end{array}$ & Full $(27 \mathrm{~cm})$ & & & $79-100$ & & 52 \\
\hline $\begin{array}{l}\text { Pentachlorophenol, } \\
\text { 3-bromobenzoic } \\
\text { acid, 4-iodobenzoic } \\
\text { acid }\end{array}$ & $\begin{array}{l}\text { SDME- } \\
\text { LVSEP- } \\
\text { NACE-UV }\end{array}$ & Bare & $\begin{array}{l}25 \mathrm{mM} \text { Tris/ } \\
\text { acetate }(25: 9.9, \\
\mathrm{v} / \mathrm{v}, \mathrm{pH} 8.0) / \\
\text { methanol }\end{array}$ & Full $(27 \mathrm{~cm})$ & & $\begin{array}{l}0.3- \\
0.7 \mathrm{nM}\end{array}$ & $\begin{array}{c}5400- \\
7300\end{array}$ & & 52 \\
\hline $\begin{array}{l}\text { Phenols, } \\
\text { dichlorocinnamic } \\
\text { acid }\end{array}$ & $\begin{array}{l}\text { LVSEP- } \\
\text { NACE-MS }\end{array}$ & Bare & $\begin{array}{l}25 \mathrm{mM} \mathrm{NH}_{4} \mathrm{OH} \\
(\mathrm{pH} \mathrm{8.0)/} \\
\text { methanol }\end{array}$ & Full $(80 \mathrm{~cm})$ & & $4-8 n M$ & $256-493$ & ESI-MS & 53 \\
\hline
\end{tabular}

a. SDME, single drop microextraction; ESI, electrospray ionization.

PFACE, the peak intensities of oligosaccharides were reduced by injecting the lectin plug, while conventional PFACE gave only a gradual broadening and retardation. The difference between the affinity profiles in these two modes may be due to the difference in the interaction profiles. Since the sample components were stacked at the sample/buffer boundary for a long time in LVSEP-PFACE, the lectin and saccharides interacted under the static conditions, which enhanced the affinity profiling efficiency. Therefore, combining the LVSEP method with PFACE will be useful in the profiling of minor components in glycans.

\section{LVSEP Combined with NACE}

In $\mathrm{CE}$, the separation mode based on the organic-solvent BGSs is named NACE. When organic solvents such as methanol and acetonitrile are used as the BGS solvent, appropriate suppression of the EOF allows LVSEP simply with a bare fused-silica capillary. Kim et al. reported a highly sensitive LVSEP-NACE of weakly acidic organic compounds by using methanol as the BGS solvent. ${ }^{47}$ They found that methanol was a suitable solvent for LVSEP because the absolute value of the electrophoretic mobilities of aromatic acids and phenols ranging from 2.7 to $3.5 \times 10^{-4} \mathrm{~cm}^{2} / \mathrm{V} \cdot \mathrm{s}$ surpassed that of the EOF mobility of $1.8 \times 10^{-4} \mathrm{~cm}^{2} / \mathrm{V} \cdot \mathrm{s}$ in methanol. Furthermore, the electrophoretic velocities in methanol were faster than those in water due to the low viscosity of the methanol solvent, which promoted the stacking effect in the NACE mode. Actually, the separation of ten aromatic acids and phenols in methanol was superior to that in water, and sensitivity improvements using LVSEP are more feasible in NACE. The same LVSEP-NACE approach using methanol BGS has been applied to the analysis of nonsteroidal anti-inflammatory drugs (NSAIDs), ${ }^{48,49}$ halogenated phenols, ${ }^{50-52}$ and benzoic acids ${ }^{52}$ typically with $50-300$-fold sensitivity increases. Since organic-solvent BGSs with high-pH can be employed to NACE, most weak acids and phenolic compounds, which are easily dissociated at high $\mathrm{pH}$, even in organic solvents, are possible to be concentrated by LVSEP.

The combination of LVSEP with NACE has a significant advantage, i.e., sample preparation can be simplified, since concentrated extracts eluted from a solid-phase extraction (SPE) cartridge with organic solvents or from a liquid-liquid extraction can be injected directly into the NACE system without any further treatment. Macià et al. reported that NASAIDs in a real water sample pretreated by SPE was analyzed by LVSEPNACE, improving the sensitivity by as much as 1000 times. ${ }^{48,49}$ Blanco et al. developed a determination method for tetrabromobisphenol $\mathrm{A}$ and other phenolic compounds in environmental matrices. ${ }^{50,51}$ By the off-line coupling of SPE with LVSEP-NACE, the sensitivity was improved by $3300-$ 4500-fold and 1600 - 2200-fold for river water and wastewater 


\section{A V-cut reservoir}

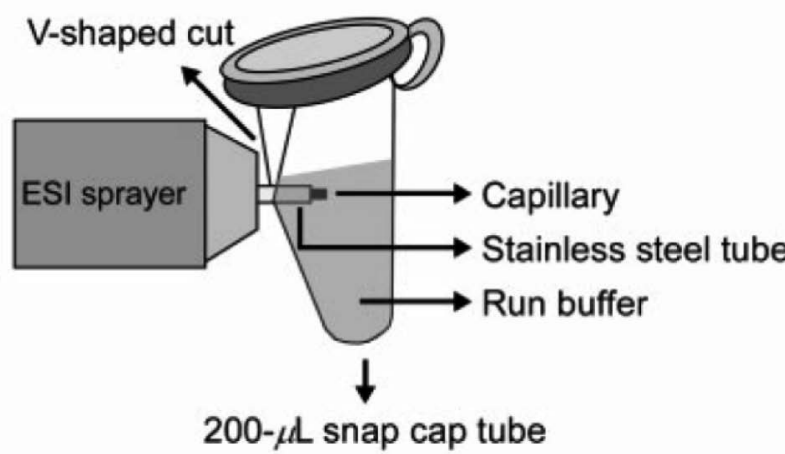

B Rubber seal reservoir

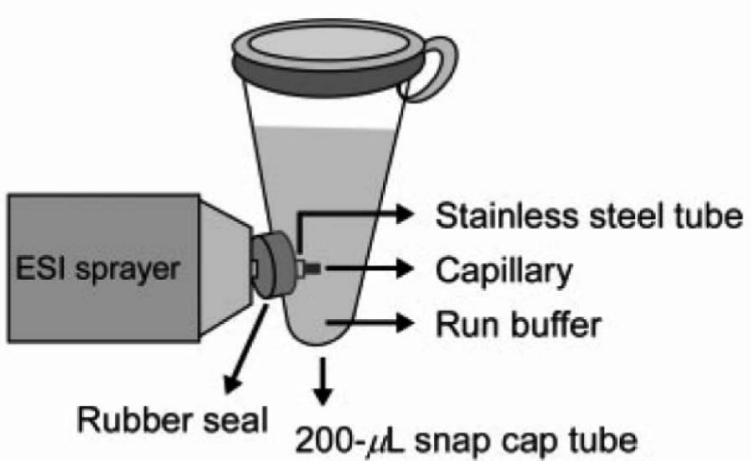

Fig. 4 Outlet reservoirs for LVSEP CE/ESI-MS. [Reprinted with permission from Electrophoresis, 2009, 30, 1046. Copyright 2009 WILEY-VCH Verlag GmbH \& Co. KGaA, Weinheim.]

samples, respectively. Choi et al. reported the on-line hyphenation of single drop microextraction (SDME) with LVSEP-NACE in a commercial CE instrument. ${ }^{52}$ Pentachlorophenol and benzoic acids from an acidic aqueous donor solution were extracted to a large pentanol drop hanging at the capillary tip with a Teflon sleeve. The pentanol drop was enriched with the analytes by SDME, and then injected into the entire capillary for subsequent preconcentration and separation by LVSEP-NACE with a methanolic BGS, yielding SEFs of $5400-7300$. As demonstrated above, the sample cleanup by SPE or SDME is compatible with LVSEP-NACE, which is helpful to analyze minor components in crude matrices with minimal pretreatment.

In the hyphenation of LVSEP-CE with electrospray ionization MS (ESI-MS) detection, it is necessary to supply BGS from the outlet end of the capillary, which is conflicted with the open end of the capillary outlet in most ESI-MS configurations, since SM removal must occur by introducing the BGS from the outlet. Kim et al. solved this difficulty simply by placing a centrifuge tube filled with the BGS at the end of the CE-ESI-MS interface to supply the reverse flow of the BGS for the EOF pumping process from the outlet to the inlet of the capillary. ${ }^{53}$ Two different types of outlet reservoir vial were examined: one with a $\mathrm{V}$ cut, and one with a rubber seal, as shown in Fig. 4. In the V-cut reservoir, the ESI tip was placed in the V-cut and immersed in the BGS for a quick and easy application of LVSEP. For usual applications of LVSEP, the outlet reservoir with a rubber seal was more convenient. Since most of the BGS inside the reservoir can be used for reverse flow without loss by
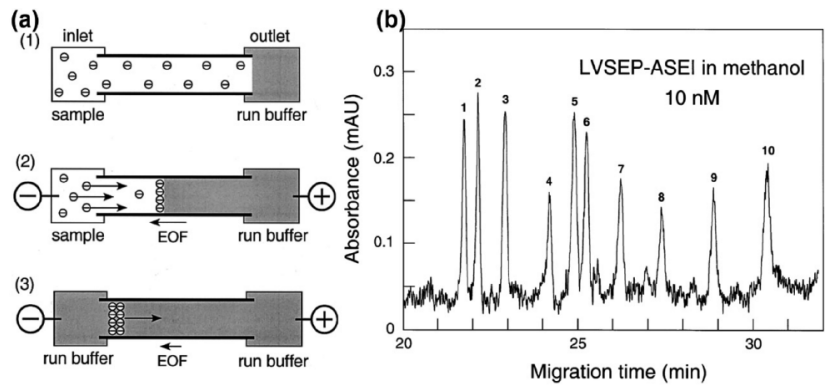

Fig. 5 (a) Schematic representation of LVSEP-ASEI. (b) LVSEPASEI analysis of ten benzoic acids. Hydrodynamic injection of $10 \mathrm{nM}$ analytes in methanol for $2 \mathrm{~min}$ at $20 \mathrm{psi}$ and then an additional amount of the analytes was loaded electrokinetically for $8 \mathrm{~min}$ under a reversal voltage of $-15 \mathrm{kV}$; the applied voltage during separation was $-25 \mathrm{kV}$. [Reprinted with permission from Electrophoresis, 2002, 23, 49. Copyright 2002 WILEY-VCH Verlag GmbH \& Co. KGaA, Weinheim.]

evaporation. By using methanolic BGS, the EOF in a bare fused-silica capillary was suppressed to allow LVSEP of anions under a reverse potential. This LVSEP-NACE-ESI-MS successfully provided the preconcentration, separation and MS detection of six anionic phenols, achieving a 400-fold improvement in the detection sensitivity. Since the coupling of CE with MS has attracted much attention for rapid identification and structural characterization, the demands of the hyphenation with highly efficient on-line sample preconcentration techniques including LVSEP will be increased.

\section{LVSEP Combined with Electrokinetic Injection}

In the conventional LVSEP technique, it is difficult to achieve drastic sensitivity improvements, since the sample volume in LVSEP-CE/MCE by the hydrodynamic injection is limited up to the whole capillary/microchannel volume. To increase the sample injection volume, the combination of LVSEP with another concentration technique based on the electrokinetic injection scheme, such as field-amplified sample injection $(\mathrm{FASI})^{54}$ and anion-selective exhaustive injection (ASEI), ${ }^{55}$ is desired. In electrokinetic injection, the ionic analytes are continuously concentrated with the electrokinetic sample supply from the inlet vial/reservoir up to their volumes. Kim et al. reported a highly sensitive analysis of ten benzoic acids by the field-amplified sample injection of an additional amount of analytes during vacant sample plug (pure methanol) removal in LVSEP-NACE. ${ }^{47}$ During preconcentration by the normal LVSEP mechanism, and removal of the methanol plug, an additional amount of the analytes was injected electrokinetically under a reversal potential, as shown in Fig. 5a. Due to cooperative concentration effects of the ASEI and LVSEP, the LODs of benzoic acids were improved to below the nanomolar range with conventional UV absorption detection (Fig. 5b). LVSEP-ASEI-NACE was also applied to the analysis of NSAIDs, resulting in the SEFs by $1200 .{ }^{49}$ Wang et al. combined LVSEP-ASEI and ACE using vancomycin as the chiral selector for fenoprofen and amino acid enantiomers. ${ }^{56}$ To suppress the EOF and the adsorption of vancomycin, and to improve the separation performance, a poly(dimethylacrylamide) (PDMA) coated capillary was employed. By using LVSEP-ASEI-ACE, the enantioseparation of fenoprofen as low as $0.38 \mathrm{ng} / \mathrm{mL}$ for each enantiomer in pure water could be detected, which was 
Table 4 Applications of LVSEP combined with the electrokinetic injection ${ }^{\mathrm{a}}$

\begin{tabular}{|c|c|c|c|c|c|c|c|c|}
\hline Target analyte & $\begin{array}{l}\text { Preconcentration } \\
\text { and separation } \\
\text { mode, and } \\
\text { detection } \\
\text { scheme }\end{array}$ & $\begin{array}{l}\text { Capillary } \\
\text { coating }\end{array}$ & BGS & Injection amount & Application & LOD & SEF & Ref. \\
\hline Ten benzoic acids & $\begin{array}{l}\text { LVSEP-ASEI- } \\
\text { NACE-UV }\end{array}$ & Bare & $\begin{array}{l}25 \mathrm{mM} \text { Tris/acetate } \\
(25: 9.9 \mathrm{v} / \mathrm{v} \\
\mathrm{pH} 8.0) / \text { methanol }\end{array}$ & $\begin{array}{l}\text { Full }(57 \mathrm{~cm})+15 \mathrm{kV} \\
\text { for } 8 \mathrm{~min}\end{array}$ & & $\begin{array}{l}0.5- \\
4 \mathrm{nM}\end{array}$ & $300-430$ & 47 \\
\hline $\begin{array}{l}\text { Five nonsteroidal } \\
\text { antiinflammatory } \\
\text { drugs }\end{array}$ & $\begin{array}{l}\text { LVSEP-ASEI- } \\
\text { NACE-UV }\end{array}$ & Bare & $\begin{array}{l}30 \mathrm{mM} \text { borate } \\
(\mathrm{pH} 9.8) / 70 \% \\
\text { methanol }\end{array}$ & $\begin{array}{l}\text { Full }(52 \mathrm{~cm})+10 \mathrm{kV} \\
\text { for } 12 \mathrm{~min}\end{array}$ & & $\begin{array}{l}0.2- \\
1.0 \mu \mathrm{g} / \mathrm{L}\end{array}$ & $800-1200$ & 49 \\
\hline $\begin{array}{l}\text { Fenoprofen and } \\
\text { amino acid } \\
\text { enantiomers }\end{array}$ & $\begin{array}{l}\text { LVSEP-ASEI- } \\
\text { ACE-UV }\end{array}$ & PDMA & $\begin{array}{l}2 \mathrm{mM} \text { vancomycin/ } \\
100 \text { mM Tris- } \\
\text { phosphate buffer } \\
\text { (pH 6.0) }\end{array}$ & $\begin{array}{l}32 \mathrm{~cm} \text { by pressure }+ \\
5 \mathrm{kV} \text { for } 12.5 \mathrm{~min}\end{array}$ & & $\begin{array}{l}0.38- \\
2.1 \mathrm{ng} / \\
\mathrm{mL}\end{array}$ & 1000 & 56 \\
\hline $\begin{array}{l}\text { Fluorescein, } \\
\text { oligosaccharides }\end{array}$ & $\begin{array}{l}\text { PAEKI- } \\
\text { LVSEP-CZE- } \\
\text { LIF }\end{array}$ & PVA & $\begin{array}{l}25 \text { mM HEPES } \\
\text { buffer (pH 8.0) }\end{array}$ & $200 \mu \mathrm{L}$ & & & $\begin{array}{l}110000 \\
\text { (fluorescein), } \\
2800-10000 \\
\text { (oligosaccharides) }\end{array}$ & 57 \\
\hline $\begin{array}{l}\text { Phenoxy acid } \\
\text { herbicides }\end{array}$ & $\begin{array}{l}\text { FAEP-CZE- } \\
\text { UV }\end{array}$ & HEC & $\begin{array}{c}0.1 \% \mathrm{HEC} / 48 \mathrm{mM} \\
\mathrm{Na}_{2} \mathrm{~B}_{4} \mathrm{O}_{7}-\mathrm{H}_{3} \mathrm{PO}_{4} \\
\text { buffer }(\mathrm{pH} \mathrm{3.33)}\end{array}$ & $\begin{array}{l}400 \mathrm{mbar} \text { for } 1.0 \mathrm{~min} \\
+10 \mathrm{kV} \text { for } 16 \mathrm{~min}\end{array}$ & River water & & 3000 & 58 \\
\hline $\begin{array}{l}\text { Five nonsteroidal } \\
\text { anti-inflammatory } \\
\text { drugs }\end{array}$ & $\begin{array}{l}\text { FAEP-NACE- } \\
\text { UV }\end{array}$ & Bare & $\begin{array}{l}30 \mathrm{mM} \text { borate } \\
(\mathrm{pH} 9.8) / 70 \% \\
\text { methanol }\end{array}$ & $\begin{array}{l}28.5 \mathrm{~cm} \text { for solvent } \\
\text { plug }+10 \mathrm{kV} \text { for } \\
170 \mathrm{~s}\end{array}$ & Water & $\begin{array}{l}0.1- \\
0.4 \\
\mu \mathrm{g} / \mathrm{L}\end{array}$ & $1200-1800$ & 59 \\
\hline Herbicides & $\begin{array}{l}\text { SMBE-FAEP- } \\
\text { NACE-UV }\end{array}$ & Bare & $\begin{array}{l}25 \mathrm{mM} \text { ammonium } \\
\text { acetate, } 1 \mathrm{M} \text { acetic } \\
\text { acid/methanol }\end{array}$ & $\begin{array}{l}50 \mathrm{mbar}, 2 \mathrm{~s} \text { for } \\
\text { solvent plug }+10 \mathrm{kV} \\
60 \mathrm{~s} \text { for sample }\end{array}$ & River water & $\begin{array}{l}0.08- \\
0.14 \mathrm{ng} / \\
\mathrm{mL}\end{array}$ & & 60 \\
\hline
\end{tabular}

a. FAEP, field-amplified sample injection and pre-introduced solvent plug removal with the EOF as a pump; HEC, hydroxyethylcellulose; SBME, solvent-bar microextraction; ASEI, anion-selective exhaustive injection; PDMA, poly(dimethylacrylamide); PAEKI, pressureassisted electrokinetic injection.

about a 1000-fold enhancement in the detection sensitivity compared that with the normal injection. Very recently, our research group reported a combination of LVSEP and pressureassisted electrokinetic injection (PAEKI) for an extremely highly sensitive analysis of oligosaccharides. ${ }^{57}$ This PAEKILVSEP technique is a modification of ASEI-LVSEP, i.e., pressure is applied from the inlet during electrokinetic injection to delay the SM removal, and then to keep the stacking boundary near the inlet of the capillary when the pressure-induced counter-flow and the EOF are balanced. The formation of the static stacking boundary allows a long and efficient electrokinetic injection of analytes. Under the optimal condition, a model fluorescent analyte, fluorescein, was detected as a considerably sharp and high peak in LVSEP-PAEKI-CZE, where the obtained SEF was estimated to be 110000 at an electrokinetic injection time of $15 \mathrm{~min}$. In an analysis of the glucose oligomer, furthermore, up to 8600-fold sensitivity increases were achieved without reducing the separation performance obtained with a conventional CZE.

As a related technique with LVSEP-ASEI, Zhu et al. combined FASI with the EOF pump, which was named field-amplified injection, and water removal using the EOF pump (FAEP), to separate phenoxy acid herbicides. ${ }^{58}$ Figure 6 shows schematics of the FAEP process. First, a long plug of water plug is injected to form a high electric field at the injection point (Fig. 6a). After injection of the water plug, a negative voltage is applied to inject phenoxy acid anions from a reservoir containing the sample in water, where the anions are enriched by FASI at the water/BGS boundary (Figs. $6 \mathrm{~b}$ and $6 \mathrm{c}$ ). After electrokinetic injection, the inlet reservoir is changed to high- $I$ BGS, and a high voltage is applied to remove the water using an EOF pump, which is the LVSEP process (Fig. 6d). When the water plug completely moves out, the analytes begin to separate, since their electrophoretic velocities exceed the EOF suppressed by introducing of the BGS from the outlet (Fig. 6e). In FAEP, a slow removal of the water plug by the EOF is necessary to attain a long electrokinetic injection time, giving high preconcentration efficiencies. In the first FAEP study, eight phenoxy acid herbicides were concentrated with the sensitivity enhancement as high as 3000-fold at the sample injection time of $16 \mathrm{~min}$, and well separated by CZE in an acidic BGS containing the HEC polymer. ${ }^{58}$ Combined with SPE, furthermore, LODs for the phenoxy acid herbicides as low as $0.01 \mathrm{ng} / \mathrm{mL}$ could be achieved. Macià et al. reported that the FAEP technique was coupled with NACE to analyze NSAIDs. ${ }^{59}$ In the report, three LVSEP-related techniques (conventional LVSEP, LVSEP-ASEI and FAEP) were compared. Among them, FAEP gave the best sensitivity enhancement. For further improvement of the sensitivity, FAEP-NACE was combined with solvent-bar microextraction (SBME). ${ }^{60}$ Due to the compatibility of the extractant organic solvent and the NACE separation system, the extract could be introduced directly to the $\mathrm{CE}$ system after SBME. LODs of between 0.08 and $0.14 \mathrm{ng} / \mathrm{mL}$ for herbicides were achieved by SBME-FAEP. Such combinations of the electrophoretic on-line sample preconcentration and the extraction techniques should progress for real sample analysis. 


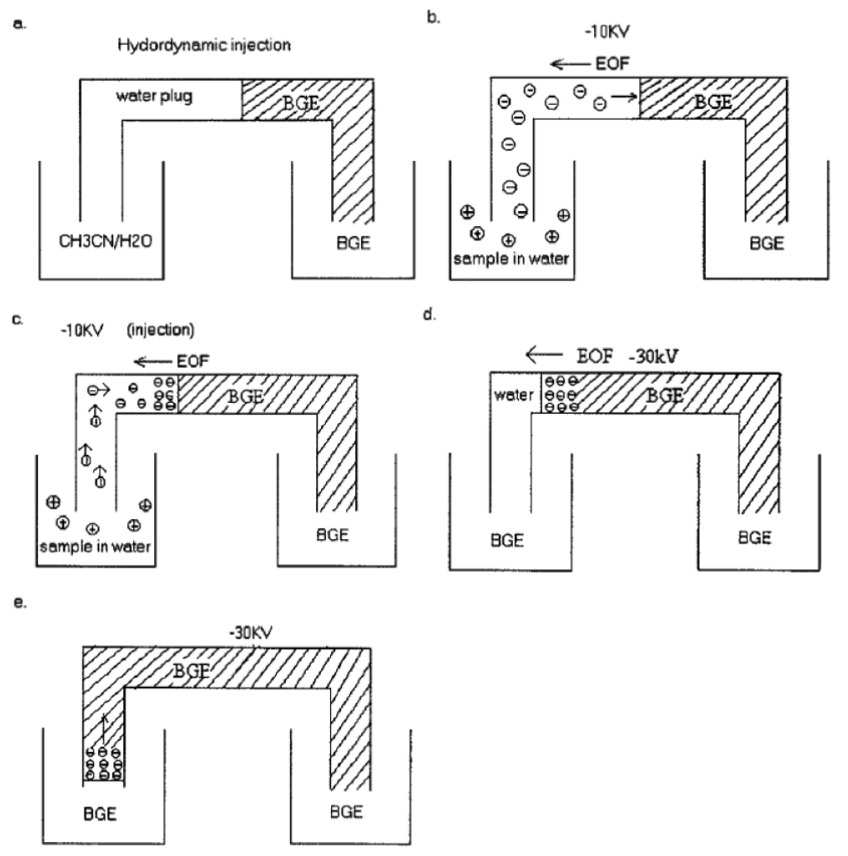

Fig. 6 Schematic illustration of the field-amplified injection and sample-stacking process: a, initial condition, injection of long plug of water into the capillary by pressure; $b$, field-amplified injection of anions into the capillary under negative voltage; $\mathrm{c}$, water comes out from the inlet slowly during the injection process; $d$, process of anion stacking and removal of aqueous sample plug; e, complete removal of aqueous sample plug and start of separation under negative voltage. [Reprinted with permission from Anal. Chem., 2001, 73, 3065. Copyright 2001 American Chemical Society.]

\section{Conclusions}

In this review, recent developments and applications of on-line sample preconcentration by LVSEP are overviewed in CE and MCE. LVSEP significantly increases the sensitivity without loss of the resolution due to whole capillary/microchannel sample injection and its reverse migration behavior near the inlet, respectively. By combining LVSEP with MCE, furthermore, a highly simplified experimental system can be realized with omitting complicated electrokinetic injection schemes. Since the suppression of EOF is an important factor to achieve efficient preconcentration and successive separation of fast-migrating ionic analytes without polarity switching, LVSEP is compatible with the neutral polymer-coated separation columns and/or NACE. Polymer-coated columns facilitate the application of LVSEP to bioanalysis due to its ability to suppress the surface adsorption of biomolecules, which is useful in the proteomics, peptidomics, glycomics and metabolomics research fields. Good compatibility with NACE is also reliable, especially to combine LVSEP with ESI-MS detection. Coupling LVSEP with the electrokinetic injection techniques can considerably enhance the detectability, providing the applicability to the analysis of minor and trace components in biomatrices, foods, pharmaceuticals and environmental samples.

\section{Acknowledgements}

This work was supported in part by a Grant-in-Aid for Scientific Research (C) (No. 24550090) from the Japan Society for the
Promotion of Science (JSPS). This research was also supported by SENTAN, JST.

\section{References}

1. A. Sarafraz-Yazdi and A. Amiri, TrAC, Trends Anal. Chem., 2010, $29,1$.

2. Z. A. ALOthmana, M. Dawod, J. Kim, and D. S. Chung, Anal. Chim. Acta, 2012, 739, 14.

3. Z. K. Shihabi, J. Chromatogr., A, 2000, 902, 107.

4. J. L. Beckers and P. Boček, Electrophoresis, 2000, 21, 2747.

5. J. P. Quirino, J.-B. Kim, and S. Terabe, J. Chromatogr., A, 2002, 965, 357.

6. A. R. Timerbaev and T. Hirokawa, Electrophoresis, 2006, 27, 323.

7. S. L. Simpson Jr., J. P. Quirino, and S. Terabe, J. Chromatogr., A, 2008, 1184, 504.

8. A. T. Aranas, A. M. Guidote Jr., and J. P. Quirino, Anal. Bioanal. Chem., 2009, 394, 175.

9. A. A. Kazarian, E. F. Hilder, and M. C. Breadmore, J. Sep. Sci., 2011, 34, 2800.

10. Y. Wen, J. Li, J. Ma, and L. Chen, Electrophoresis, 2012, 33, 2933.

11. S. S. Bahga and J. G. Santiago, Analyst, 2013, 138, 735.

12. D. S. Burgi and R.-L. Chien, Anal. Chem., 1991, 63, 2042.

13. R. L. Chien and D. S. Burgi, Anal. Chem., 1992, 64, 1046.

14. D. S. Burgi and R.-L. Chien, Anal. Biochem., 1992, 2, 308.

15. R.-L. Chien and D. S. Burgi, Anal. Chem., 1992, 64, 489A.

16. D. S. Burgi, Anal. Chem., 1993, 65, 3726.

17. S. Mallampati, K. Wolfs, M. M. Pendela, J. Hoogmartens, and A. Van Schepdael, J. Liq. Chromatogr., 2010, 33, 802.

18. W. F. Smytha, G. B. Harlanda, S. McCleana, G. McGrathb, and D. Oxspringa, J. Chromatogr., A, 1997, 772, 161.

19. M. Albert, L. Debusschere, C. Demesmay, and J. L. Rocca, J. Chromatogr., A, 1997, 757, 291.

20. Z. L. Chen and R. Naidu, J. Chromatogr., A, 2004, 1023, 151.

21. B. Sun, M. Macka, and P. R. Haddad, Electrophoresis, 2003, 24, 2045.

22. N. Maeso, A. Cifuentes, and C. Barbas, J. Chromatogr., B, 2004, 809, 147.

23. W. S. Law, J. H. Zhao, and S. F. Y. Li, Electrophoresis, 2005, 26, 3486.

24. J. P. Quirino and S. Terabe, Electrophoresis, 2000, 21, 355.

25. J. P. Quirino and S. Terabe, J. Chromatogr., A, 1999, 850, 339.

26. H. H. See, P. C. Hauser, W. A. W. Ibrahim, and M. M. Sanagi, Electrophoresis, 2010, 31, 575.

27. N. E. Baryla and C. A. Lucy, Electrophoresis, 2001, 22, 52.

28. S. Morales and R. Cela, Electrophoresis, 2002, 23, 408.

29. E. Blanco, M. C. Casais, M. C. Mejuto, and R. Cela, Anal. Chem., 2006, 78, 2772.

30. P.-L. Laamanen, E. Blanco, R. Cela, and R. Matilainen, $J$. Chromatogr., A, 2006, 1110, 261.

31. E. Blanco, M. C. Casais, M. C. Mejuto, and R. Cela, Electrophoresis, 2008, 29, 3229.

32. E. Blanco, M. C. Casais, M. C., Mejuto, and R. Cela, Anal. Chim. Acta, 2009, 647, 104.

33. Y. He and H. K. Lee, Anal. Chem., 1999, 71, 995.

34. J. H. Han, M.-S. Chun, A. Riaz, and D. S. Chung, Electrophoresis, 2005, 26, 480.

35. J. H. Lee, O.-K. Choi, H. S. Jung, K.-R. Kim, and D. S. Chung, Electrophoresis, 2000, 21, 930. 
36. M.-S. Chun, D. Kang, Y. Kim, and D. S. Chung, Microchem. J., 2001, 70, 247.

37. M.-S. Chun and D. S. Chung, Anal. Chim. Acta, 2003, 491, 173.

38. S. T. Park, J. Kim, K. Choi, H. R. Lee, and D. S. Chung, Electrophoresis, 2012, 33, 2961.

39. Z. Zhu, L. Zhang, A. Marimuthu, and Z. Yang, Electrophoresis, 2002, 23, 2880.

40. C.-Y. Kuo, S.-S. Chiou, and S.-M. Wu, Electrophoresis, 2006, 27, 2905.

41. T. Kawai, K. Sueyoshi, F. Kitagawa, and K. Otsuka, Anal. Chem., 2010, 82, 6504.

42. T. Kawai, M. Watanabe, K. Sueyoshi, F. Kitagawa, and K. Otsuka, J. Chromatogr., A, 2012, 1232, 52.

43. T. Kawai, J. Ito, K. Sueyoshi, F. Kitagawa, and K. Otsuka, J. Chromatogr., A, 2012, 1267, 65.

44. Z. Zhu, L. Zhang, A. Marimuthu, and Z. Yang, Electrophoresis, 2003, 24, 3089.

45. T. Kawai, H. Koino, K. Sueyoshi, F. Kitagawa, and K. Otsuka, J. Chromatogr., A, 2012, 1246, 28.

46. E. Fukushima, Y. Yagi, S. Yamamoto, Y. Nakatani, K. Kakehi, T. Hayakawa, and S. Suzuki, J. Chromatogr., A, 2012, 1246, 84.

47. B. Kim and D. S. Chung, Electrophoresis, 2002, 23, 49.

48. A. Macia, F. Borrull, C. Aguilar, and M. Calull,
Electrophoresis, 2003, 24, 2779.

49. A. Macia, F. Borrull, C. Aguilar, and M. Calull, Electrophoresis, 2004, 25, 428.

50. E. Blanco, M. C. Casais, M. C. Mejuto, and R. Cela, J. Chromatogr., A, 2005, 1068, 189.

51. E. Blanco, M. C. Casais, M. C. Mejuto, and R. Cela, J. Chromatogr., A, 2005, 1071, 205.

52. K. Choi, Y. G. Jin, and D. S. Chung, J. Chromatogr., A, 2009, 1216, 6466.

53. J. Kim, M.-S. Chun, K. Choi, and D. S. Chung, Electrophoresis, 2009, 30, 1046.

54. R.-L. Chien and S. D. Burgi, J. Chromatogr., 1991, 559, 141.

55. J.-B. Kim, K. Otsuka, and S. Terabe, J. Chromatogr., A, 2001, 932, 129.

56. Z. Wang, C. Liu, and J. Kang, J. Chromatogr., A, 2011, $1218,1775$.

57. T. Kawai, M. Ueda, Y. Fukushima, K. Sueyoshi, F. Kitagawa, and K. Otsuka, Electrophoresis, 2013, 34, 2303.

58. L. Zhu and H. K. Lee, Anal. Chem., 2001, 73, 3065.

59. A. Macia, F. Borrull, C. Aguilar, and M. Calull, Electrophoresis, 2004, 25, 428.

60. L. Xu, C. Basheer, and H. K. Lee, J. Chromatogr., A, 2010, 1217, 6036. 